\title{
Angiotensin-converting enzyme 2: a double-edged sword in COVID-19 patients with an increased risk of heart failure
}

\author{
Iman Razeghian-Jahromi ${ }^{1} \cdot$ Mohammad Javad Zibaeenezhad $^{1} \cdot$ Zhibing Lu $^{2}$ - Elyaspour Zahra ${ }^{1}$. \\ Razmkhah Mahboobeh ${ }^{3}$. Vicenzo Lionetti ${ }^{4,5}$
}

Published online: 25 August 2020

(C) Springer Science+Business Media, LLC, part of Springer Nature 2020

\begin{abstract}
The coronavirus disease (COVID-19) pandemic is a global health priority. Given that cardiovascular diseases (CVD) are the leading cause of morbidity around the world and that several trials have reported severe cardiovascular damage in patients infected with SARS-CoV-2, a substantial number of COVID-19 patients with underlying cardiovascular diseases need to continue their medications in order to improve myocardial contractility and to prevent the onset of major adverse cardiovascular events (MACEs), including heart failure. Some of the current life-saving medications may actually simultaneously expose patients to a higher risk of severe COVID-19. Angiotensinconverting enzyme 2 (ACE2), a key counter regulator of the renin-angiotensin system (RAS), is the main entry gate of SARS-CoV-2 into human host cells and an established drug target to prevent heart failure. In fact, ACE inhibitors, angiotensin II receptor blockers, and mineralocorticoid antagonists may augment ACE2 levels to protect organs from angiotensin II overload. Elevated ACE2 expression on the host cell surface might facilitate viral entrance, at the same time sudden nonadherence to these medications triggers MACEs. Hence, safety issues in the use of RAS inhibitors in COVID-19 patients with cardiac dysfunction remain an unsolved dilemma and need paramount attention. Although ACE2 generally plays an adaptive role in both healthy subjects and patients with systolic and/or diastolic dysfunction, we conducted a literature appraisal on its maladaptive role. Understanding the exact role of ACE2 in COVID-19 patients at risk of heart failure is needed to safely manage RAS inhibitors in frail and non-frail critically ill patients.
\end{abstract}

Keywords ACE2 $\cdot$ Angiotensin II $\cdot$ RAS inhibitors $\cdot$ COVID-19 $\cdot$ Heart failure $\cdot$ SARS-CoV-2

Iman Razeghian-Jahromi

razejahromi@yahoo.com

Vicenzo Lionetti

vincenzo.lionetti@santannapisa.it

1 Cardiovascular Research Center, Shiraz University of Medical Sciences, Shiraz, Iran

2 Department of Cardiology, Zhongnan Hospital of Wuhan University, Wuhan, China

3 Shiraz Institute for Cancer Research, Shiraz University of Medical Sciences, Shiraz, Iran

4 Unit of Translational Critical Care Medicine, Institute of Life Sciences, Scuola Superiore Sant'Anna, Pisa, Italy

5 UOS Anesthesiology and Intensive Care Medicine, Fondazione Toscana G. Monasterio, Pisa, Italy

\section{Introduction}

\section{The outbreak of COVID-19: an unexpected Pandora's} box

A few months after the emergence of the coronavirus disease (COVID-19) in China and during the outbreak peak in Italy [1], on 11 March 2020, the World Health Organization (WHO) claimed that the new viral disease was considered a pandemic. However, the global rate of severe acute respiratory syndrome coronavirus 2 (SARS-CoV-2) transmission was and is still significant in several countries including Spain, Brazil and the USA [2]. Easy human-to-human transmission of SARS-CoV-2 compared with previous coronaviruses (SARS-CoV, MERS-CoV) may be due to the fact that the infection is spread by unpredictable asymptomatic carriers [3]. In addition, the binding affinity of SARS-CoV-2 to its 
receptor on the host cell surface is $10-20$-fold higher than previous $\beta$-coronaviruses [4].

Besides epithelial cells resident in the nasal mucosa, lower airways, lung parenchyma, conjunctiva, cornea, and enteric tube [5-7], SARS-CoV-2 can also infect arterial vascular cells [8], cardiomyocytes [8], and neural cells [9].

COVID-19 is thus a specific disease with different phenotypes from the well-known adult respiratory distress syndrome (ARDS), although acute respiratory failure and severe hypoxemia are easily identifiable in infected non-intubated and intubated patients [10]. It is conceivable that heart function and vessel patency are simultaneously impaired in patients with COVID-19 pneumonia, and the magnitude of cardiovascular damage may depend on comorbidities and comedications.

\section{Cardiovascular system vulnerability and COVID-19: an emerging relationship}

Cardiovascular diseases and COVID-19 share common symptoms such as dyspnea and fatigue [11, 12], which make differential diagnosis difficult. Also, severe hypoxemia, as the ultimate pathophysiological cause of death, is detected both in heart failure and COVID-19 patients [11]. COVID-19related hypoxemia may also possibly induce atrial fibrillation as the most common arrhythmia among hospitalized individuals [13]. Atrial fibrillation is life-threatening if it becomes refractory and runs into a detrimental cycle, especially before respiratory function returns to a normal status. This condition could deteriorate particularly in the case of hypercoagulability due to an exaggerated systemic inflammatory storm in response to viral infection $[14,15]$. In fact, increasing evidence suggests that the onset of atrial fibrillation may be secondary to micro-thrombotic coronary events [16].

As expected, a cytokine storm might lead to erosion or rupture of undetectable atherosclerotic plaques [1] also in COVID-19 patients with coronary artery disease. In this situation, the patient will be exposed to a higher risk of acute myocardial infarction $[15,17]$ and acute heart failure, possibly due to the sudden formation of thrombus following plaque rupture or the spread of plaque emboli into the coronary tree. Moreover, an uncontrolled host immune response to SARSCoV-2 infection may impair diastolic function along with the onset of heart failure with preserved ejection fraction. Therefore, the cytokine storm with the key involvement of interleukin-6 has a significant impact on the heart systolic and/or diastolic function $[15,18]$.

The existence of cardiovascular disorders as a comorbidity has been reported in many patients with COVID-19 [1, 15]. Among the confirmed cases of COVID-19, hypertension, myocarditis, and heart failure have been found [15] to be the most common comorbidities in hospitalized patients [12,19]. Such patients are thus likely at a higher risk of a severe type of
COVID-19 and death compared with those without these comorbidities [15]. This clinical evidence suggests that chronic CVD makes individuals with COVID-19 more susceptible to poor outcomes.

However, there are also many reports suggesting COVID19-induced cardiovascular injuries. In fact, clinical investigators from Wuhan $[12,20]$ have reported that some patients with COVID-19 showed severe heart damage. Although there are currently contrasting findings [19,21], acute cardiac injury in terms of cardiac troponin I elevation, abnormal findings in electrocardiography and echocardiography, and arrhythmia with rapid heart rates have been diagnosed after infection with SARS-CoV-2 and could act as a risk factor of mortality. High levels of cardiac troponin I, C-reactive protein, and NTproBNP, conventional biomarkers of acute myocardial injury, have been measured in hospitalized COVID-19 patients without concomitant CVD [1, 21, 22]. Acute myopericarditis with systolic dysfunction and ST-elevation myocardial infarction and upregulated cardiac markers have been reported anecdotally [1], and confirmatory studies are still required. In a cohort study from Wuhan, acute myocardial injury, shock, and arrhythmia were reported in about 10-20\% of the studied population [19]. Cardiac dysfunction may be the result of viral infection, hypoxemia, and deterioration of an underlying undiagnosed CVD [23]. Irrespectively of a chronic CVD background or viral infection that deteriorated the cardiovascular function, these patients were at greater risk of severe heart failure and death $[12,20]$.

\section{RAS system}

The renin-angiotensin system (RAS system) is a peptidergic pathway for the regulation of myocardial homeostasis [24] and vascular-related functions including blood pressure control, blood volume control, and natriuresis [25]. In the RAS system under normal conditions, renin coverts angiotensinogen into angiotensin I (Ang I). The metabolism of Ang I into Ang II is performed by the angiotensinconverting enzyme (ACE), a peptidyl dipeptidase that removes C-terminal dipeptides [26]. Ang II is a biologically active hormone. It triggers several signaling pathways, which chronically lead to myocardial hypertrophy and increased fibrosis [27, 28] toward heart failure [29]. Ang II is also the molecule responsible for endothelial dysfunction, hypertension, vascular remodeling, and atherosclerosis [30, 31]. Ang II type I (AT1) receptors are those through which the proinflammatory effects of Ang II are promoted [32]. Adverse endothelial response to Ang II requires high levels of the endothelial von Willebrand factor [33].

On the other hand, bradykinin also plays a key role in cardiovascular function. Bradykinin has a vasodilation effect, increases vascular permeability, and lowers blood pressure 
$[34,35]$. The action of bradykinin is exerted through binding to its receptors, B1 and B2 [36]. The deleterious effects of Ang II are counterbalanced by bradykinin in normal conditions [35].

Current cardiovascular medications have long been recommended for the downregulation of Ang II and to stop the cascade of MACEs. These include ACE inhibitors, angiotensin II receptor blockers (ARBs), and mineralocorticoid receptor antagonists (MRAs) [37]. Translational studies have also suggested novel ways to dampen Ang II effects including gene-based therapeutic approaches [33, 38]. If no action is taken, ACE2 degrades Ang II and generates Ang 1-7 [39]. This Ang 1-7 with anti-inflammatory, antioxidant, vasodilatory, and natriuretic activities protects the cardiovascular system [39-41]. Although ACE2 exerts protective effects [39], a pilot study failed to demonstrate an improvement in the clinical outcome of patients with acute respiratory distress syndrome (ARDS) after administration of a recombinant form of human ACE2 [42]. Accordingly, continuing treatment of CVD by ACE inhibitors, ARBs, and MRAs is of the utmost importance [43], including in patients infected by SARSCoV-2 [2].

Bradykinin activity is largely regulated by ACE, which degrades it into an inactive form [44-46]. ACE has a much higher affinity to bradykinin than Ang I [47]. ACE inhibitors prevent the conversion of Ang I to Ang II. ACE inhibitors are also more effective in the prevention of bradykinin degradation compared with Ang II production. Consequently, use of ACE inhibitors and upcoming bradykinin signaling trigger a cascade of events such as improving vascular tone and structure, promoting thrombolysis, and enhancing vascular protection against activated platelets and leukocytes [48-51]. It is plausible that a fundamental element in the cardioprotection sequels of ACE inhibitors may contribute to bradykinin overactivation rather than a lack of Ang II [46].

ARBs inhibit the binding of Ang II to its mediator receptor (AT1). Circulating Ang II is thus trapped by ACE2 and Ang 1-7 is formed [52]. In an example of ARB therapy, a fivefold greater expression of ACE2 and increased Ang 1-7 was seen in rat models of hypertension treated with olmesartan $[53,54]$. Given that the mechanism of RAS downregulation in ARBs is different from ACE inhibitors, bradykinin is not affected by ARBs [55]. This may explain the differences in blood pressure reduction and cardiovascular protection between ACE inhibitors and ARBs [46].

Regarding MRAs, the formation of Ang II is decreased by suppressing ACE activity; on the other hand, membrane ACE2 expression is promoted, and this promotion results in reduced oxidative stress and cardiovascular support [56]. In addition, the use of MRAs is an independent predictor of higher plasma ACE2 concentrations in male rather than female heart failure patients [57] (Fig. 1).
Such findings demonstrate the potential of these drugs in the downregulation of the RAS system [58]. RAS signaling is balanced by Ang II formation due to ACE activity and its binding to AT1 on the one hand and by cleavage of Ang II by ACE2 on the other [1]. ACE inhibition with or without losartan consumption has been shown to increase plasma Ang 1-7 and reduced plasma Ang II [59]. A study on the correlation between $\mathrm{ACE}$ and ACE2 showed that ACE2 mRNA, but not ACE2 activity, is altered by the inhibition of Ang II synthesis [59]. Conversely in another study, Ang II reduced ACE2 mRNA and ACE2 activity in cardiac myocytes [60].

In seminal studies, SARS-CoV [61] and SARS-CoV-2 [62] were reported to deregulate the RAS system and induce acute lung injury through ACE2 downregulation. However, this type of lung failure could be overwhelmed by the inhibition of AT1 receptors [63]. In fact, ACE and Ang II concentrations were reported to be high in the serum of patients with acute respiratory distress syndrome and sepsis [64, 65]. A correlation was also shown between plasma renin and Ang II with the degree of organ failure and microvascular dysfunction [64]. ACE2 therapy blunted the RAS system and was accompanied by an improvement in cardiac output, suppression of plasma cytokines, reduction in nitrotyrosine levels, refined peripheral vascular resistance, and better renal perfusion in patients at risk of right ventricular failure due to pulmonary hypertension [66]. Intriguingly, it did not significantly improve the physiological and clinical manifestations of acute respiratory distress syndrome [42]. Clinical trials on ameliorating pulmonary arterial hypertension with recombinant ACE2 are underway (NCT101884051) [66].

\section{ACE2}

ACE2 is predominantly found in several organs including the bronchus, lung parenchyma, heart, endothelium, kidneys, duodenum, and small intestine. It is a type I integral membrane glycoprotein $[67,68]$. There are both membrane-bound and soluble forms of ACE2 in the body [61, 69]. Although a $42 \%$ homology was shown in residues between ACE and ACE2, ACE inhibitors had no antagonistic activity on ACE2 [70,71]. The prominent role of ACE2 in regulating cardiovascular function has been established in genetic deletion studies [72]. In an ACE2 knock out mouse model, the infusion of Ang II and recombinant ACE2 attenuated Ang II-related myocardial hypertrophy and fibrosis as well as improving diastolic function [73].

To date, the genomic sequence (up to $76 \%$ ), the entry receptor, and mechanism of entry to the host cell have been found to be similar between SARS-CoV and SARS-CoV-2. It is likely that the deployment of host machinery, virus propagation, and further viral infection will be common between the two strains [74]. However, it has not been clarified 
Fig. 1 RAS system and targets of conventional RAS inhibitors.

Ang I, angiotensin I; ACE, angiotensin-converting enzyme; Ang II, angiotensin II; Ang 1-7, angiotensin 1-7; ACEi, ACE inhibitors; MRAs, mineralocorticoid receptor agonists; ARBs, angiotensin II receptor blockers; AT1, Ang II type I receptors

\section{Renin-angiotensin system}

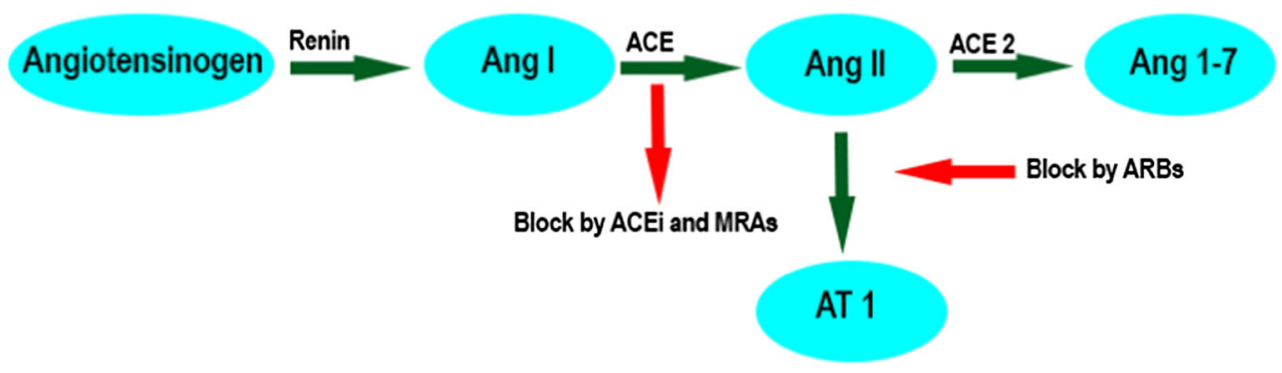

whether they have a similar biological activity [69]. Given that both $\square$-coronaviruses (SARS-CoV-2 and SARS-CoV) use ACE2 for invading the host cells, we cannot exclude that their spectrum of target cells are also similar [69]. SARS-CoV-2 infectivity, pathogenesis, and host range are mainly determined by its mechanism of receptor recognition [75, 76]. Shedding light into the virus-receptor interplay is also beneficial for development of vaccines and neutralizing monoclonal antibodies as an efficient remedy [77].

Virus binding is mediated by the activated SARS-CoV-2 surface unit (S1) of its spike protein (S) [61, 69]. In fact, a serine protease (TMPRSS2) cleaves the $\mathrm{S}$ protein in an aciddependent manner at the S1/S2 sites, preparing the environment for S2 to make a fusion between viral and cellular membranes. Eventually the virus reaches the cytosol of the host cell [69]. The receptor binding domain (RBD), which contains a core and a receptor binding motif (RBM), of the spike protein is the main player in the interaction with ACE2 $[78,79]$.

In one very interesting study, the structural basis of receptor recognition by SARS-CoV-2 was demonstrated via the crystallization technique [77]. The findings showed that a larger binding interface and more connection surfaces are present in SARS-CoV-2 than SARS-CoV. Conformation of the loops in the ACE2-binding ridge is notably different between these two strains in the way that more contacts are formed by SARS-CoV-2 with ACE2, which in turn facilitates receptor binding. Specific structural features in the ACE2binding ridge at RBM of the SARS-CoV-2 as well as hot spot-stabilizing residues at the RBM-ACE2 interface increase the binding affinity. It also seems that these changes augment its animal to human transmission. Overall, it was concluded that SARS-CoV-2 has been equipped with strategies to better recognize ACE2 and make a stronger connection [77].

Binding of the virus to the ACE2 changes the activity of the tumor necrosis factor $\alpha$-converting enzyme and promotes ACE2 ectodomain cleavage $[2,74]$. Ectodomain release triggers one of the important manifestations of COVID-19, called the cytokine storm. This storm involves an array of biochemical cytokines including interleukin 2 , interleukin 7 , interleukin 10, granulocyte colony stimulating factor, interferon gamma-induced protein 10 , monocyte chemoattractant protein 1 , macrophage inflammatory protein $1-\alpha$, and tumor necrosis factor- $\alpha$ [12]. The downregulation of ACE2 is one of the consequences of this release, which has been observed in acute lung injury [80] and post myocardial infarction [81]. This injury may be due to an excess of Ang II. Interestingly, the activity of plasma ACE2 correlated with a reduced left ventricular ejection fraction and adverse clinical outcomes [82].

If membrane-bound ACE2 on the host cell surface decreases due to ectodomain release following SARS-CoV-2 entry, the concentration of circulating ACE2 will be increased without interruption in viral propagation. In this case, the membrane-bound ACE2 is predicted to downregulate with its downstream signaling pathways, which provokes systemic inflammation and injures a multitude of organs. The use of RAS downregulators including ACE inhibitors, ARBs, and MRAs would thus be beneficial by over expressing the ACE2 and reducing the endogenous Ang II. This would lead to compensatory anti-inflammatory, antifibrotic, and antithrombotic consequences [2, 83].

The origin of the association between ACE2, membranebound or circulating, and the severity of tissue damage ultimately lies in the extent of upregulation of systemic inflammatory response $[2,83]$. Soluble ACE2 also has the potential to regulate systemic Ang II. Recombinant ACE2 converts endogenous Ang II into Ang 1-7 [42, 66]. In a mouse model of acute lung injury by lipopolysaccharide, inflammation and lung injury were observed following ACE2 downregulation. The infusion of transfected cells with ACE2 improved lung function. Lung injury also improved when these mice were treated with ACE inhibitors and ARBs [63].

Ectodomain release is another challenge regarding the detection and eradication of SARS-CoV-2 by the immune cells. When this virus invades the host cell and ectodomain is released, the amount of ACE2 at the surface of the host cell decreases. Following transcription of the spike protein, $\mathrm{S} 1$ fuses directly to the membrane of neighboring cells through the formation of multinucleated syncytia and culminates the propagation of SARS-CoV-2. 
As the virus hides in these syncytia, the neutralizing antibodies are not able to detect them [84].

ACE2 appears to play a paradoxical role in COVID-19 patients with CVD (Fig. 2). It protects the cardiovascular system from harm due to hypertension, myocardial fibrosis, myocardial hypertrophy, arrhythmia, atherosclerosis, and sodium retention. In contrast, ACE2 is highly expressed upon the use of RAS system inhibitors which unfortunately might provide more entry gates (ACE2) for SARS-CoV-2 [85] following S1 cleavage. As ACE inhibitors, ARBs, and MRAs are administered for hypertension, heart failure, and ischemic heart disease, close monitoring of such patients is advisable when they are infected with COVID-19. Overall, due to the anti-inflammatory, antifibrotic, and antithrombotic consequences of potentially upregulated-ACE2, this protein could be targeted as a therapy by contributing to the improvement in clinical outcomes of COVID-19 patients [86]. To date, there is no evidence supporting the discontinuation of their chronic administration [87].

There are several clinical trials regarding the effect of RAS inhibitors in COVID-19 patients (Table 1). NCT04318301 and NCT04318418 are the ongoing clinical trials on the effects of RAS inhibition and ACE2 overexpression in patients infected with SARS-CoV-2. In line with these, the effects of losartan (an ARB) in hospitalized and ambulatory COVID-19 patients are being investigated in other trials (NCT04312009, NCT04311177). Perhaps the most interesting studies on
COVID-19 individuals with comorbid CVD are those that examine the continuation or withdrawal of RAS inhibitors (NCT04330300, NCT04329195). Also, NCT04287686 is an ongoing trial on recombinant ACE2 therapy in these patients. To date, the role of ACE2 in improving or intensifying COVID-19 patients with CVD remains a mystery.

Of utmost importance in COVID-19 patients with underlying CVD is whether or not the use of ACE inhibitors, ARBs, or MRAs should be continued as these agents increase the expression of ACE2 and facilitate viral entry and infection $[53,56,81,88,89]$. Several cardiology societies such as the American College of Cardiology, the American Heart Association, the Heart Failure Society of America [90], the European Society of Cardiology [91], and the Italian Society of Cardiovascular Researchers [1] have issued statements emphasizing the continuation of RAS antagonists in CVD patients with COVID-19 due to the lack of data on increased susceptibility to COVID-19 by ACE2 over activation.

Any discussion on the management of COVID-19 patients with underlying CVD must therefore address the issue of ACE2. If possible, it is better to identify the most effective RAS system inhibitors based on an evaluation of the related risks and benefits in COVID-19 patients. The role of ACE2 in simultaneous COVID-19 infection and cardiovascular disorders urgently needs more in-depth investigations, which could lead to more effective treatments for such patients.
Fig. 2 Seesaw role of ACE2 in using (left) or misusing (right) RAS inhibitors in COVID-19 patients, which in both cases is accompanied by adverse consequences especially on the pulmonary and cardiovascular systems, respectively. ACE2, angiotensinconverting enzyme II; RAS, renin-angiotensin system; SARSCoV-2, severe acute respiratory syndrome-coronavirus-2

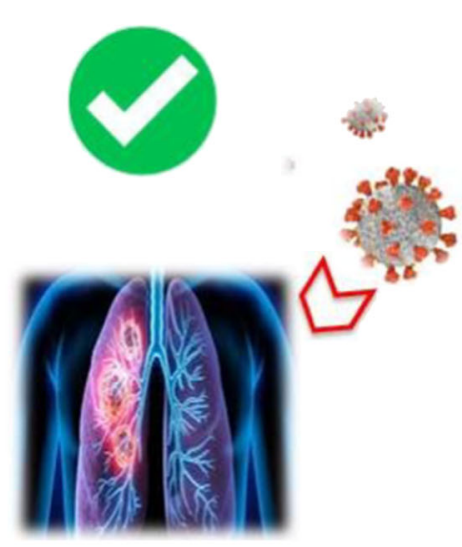

RAS inhibitors

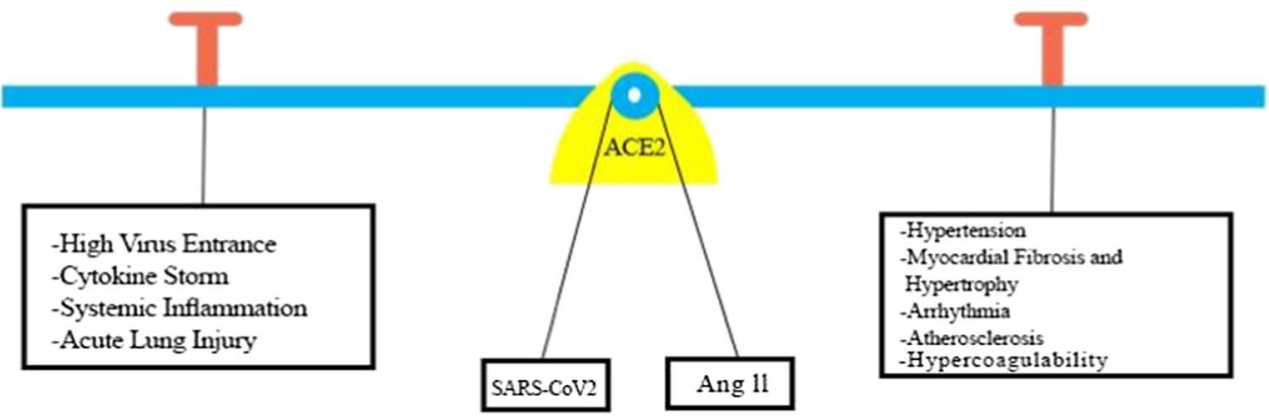


Table 1 Clinical trials investigating the association of RAS inhibitors with health outcomes in COVID-19 patients. RAS, renin-angiotensin system; $A C E i$, angiotensin-converting enzyme inhibitors; $A R B s$, angiotensin II receptor blockers; $D R I$, direct renin inhibitor

\begin{tabular}{|c|c|c|c|c|}
\hline Identifier & Status & Model & Aim & $\begin{array}{l}\text { Population } \\
\text { size }\end{array}$ \\
\hline NCT04318418 & $\begin{array}{l}\text { Not yet } \\
\text { recruiting }\end{array}$ & $\begin{array}{l}\text { Observational } \\
\text { Case-control }\end{array}$ & Association of ACEi or ARBs to severe COVID-19 & 5000 \\
\hline NCT04364893 & Recruiting & Interventional & Suspension of ACEi or ARB on the length of hospital stay and mortality & 500 \\
\hline NCT04374695 & $\begin{array}{l}\text { Not yet } \\
\text { recruiting }\end{array}$ & $\begin{array}{l}\text { Observational } \\
\text { Case-control }\end{array}$ & Relationship of ACEi and ARBs with COVID-19 infection and severity & 700 \\
\hline NCT04357535 & Terminated & Observational & Association of ACEi or ARBs with prognosis of patients with COVID-19 & 17 \\
\hline NCT04331574 & Recruiting & Observational & $\begin{array}{l}\text { Effects of chronic intake of RAS inhibitors on the prevalence and severity of the clinical } \\
\text { manifestation of COVID-19 }\end{array}$ & 2000 \\
\hline NCT04338009 & $\begin{array}{l}\text { Enrolling by } \\
\text { invitation }\end{array}$ & Interventional & $\begin{array}{l}\text { Clinical impact of continuation vs. discontinuation of ACEi and ARBs on outcomes in } \\
\text { patients hospitalized with COVID-19 }\end{array}$ & 152 \\
\hline NCT04330300 & Recruiting & Interventional & $\begin{array}{l}\text { Switch to an alternative blood pressure medication or continue with the ACEi/ARB in } \\
\text { hypertensive patients }\end{array}$ & 2414 \\
\hline NCT04345406 & $\begin{array}{l}\text { Not yet } \\
\text { recruiting }\end{array}$ & Interventional & Investigation of ACEi in treatment of COVID-19 & 60 \\
\hline NCT04353596 & Recruiting & $\begin{array}{l}\text { Interventional } \\
\text { Case-control }\end{array}$ & $\begin{array}{l}\text { The association of stopping chronic ACEi/ARB therapy in SARS-CoV-2-infected pa- } \\
\text { tients with outcomes }\end{array}$ & 208 \\
\hline NCT04374110 & Recruiting & Observational & $\begin{array}{l}\text { Monitoring of drug safety and the occurrence of complications during hospitalization in } \\
\text { patients with cardiovascular diseases with COVID-19 }\end{array}$ & 1000 \\
\hline NCT04371289 & $\begin{array}{l}\text { Not yet } \\
\text { recruiting }\end{array}$ & Observational & $\begin{array}{l}\text { Investigation of cardiovascular risk in COVID-19 patients during acute disease and at } \\
\text { short-term follow-up }\end{array}$ & 5500 \\
\hline NCT04351581 & Recruiting & Interventional & $\begin{array}{l}\text { Investigate whether to continue or discontinue treatment with ACEi or ARBs in } \\
\text { hospitalized patients with COVID-19 }\end{array}$ & 215 \\
\hline NCT04345406 & $\begin{array}{l}\text { Not yet } \\
\text { recruiting }\end{array}$ & Interventional & The effect of ACEi in the treatment of COVID-19 & 60 \\
\hline NCT04329195 & Recruiting & Interventional & $\begin{array}{l}\text { Determining whether RAS blockers should be discontinued or not in patients with } \\
\text { COVID-19 }\end{array}$ & 554 \\
\hline NCT04338009 & $\begin{array}{l}\text { Enrolling by } \\
\text { invitation }\end{array}$ & Interventional & $\begin{array}{l}\text { Assessing the clinical impact of continuation vs. discontinuation of ACEi and ARBs on } \\
\text { the outcomes in patients hospitalized with COVID-19 }\end{array}$ & 152 \\
\hline NCT04367883 & Recruiting & Observational & $\begin{array}{l}\text { Evaluation of influenza vaccination and treatment with ACEi and RAIII in the evolution } \\
\text { of SARS-COVID-19 infection }\end{array}$ & 2574 \\
\hline NCT04364984 & Recruiting & Observational & $\begin{array}{l}\text { Monitoring hypertensive patients receiving ARBs or DRI or ACEi with COVID-19 } \\
\text { infection }\end{array}$ & 10 \\
\hline NCT04353596 & Recruiting & Interventional & Stopping ACEi in patients with COVID-19 to improve outcomes & 208 \\
\hline NCT04318418 & $\begin{array}{l}\text { Not yet } \\
\text { recruiting }\end{array}$ & $\begin{array}{l}\text { Observational } \\
\text { Case-control }\end{array}$ & $\begin{array}{l}\text { The effect of treating COVID-19 patients with ARB or ACEi compared with treatment } \\
\text { without these medications }\end{array}$ & 5000 \\
\hline NCT04356417 & $\begin{array}{l}\text { Not yet } \\
\text { recruiting }\end{array}$ & Observational & $\begin{array}{l}\text { The effect of synthetic antimalarial and anti-hypertensive drugs on preventing serious } \\
\text { COVID-19 infections }\end{array}$ & $6,000,000$ \\
\hline NCT04394117 & $\begin{array}{l}\text { Not yet } \\
\text { recruiting }\end{array}$ & Interventional & Effectiveness of ARBs on improving the outcomes of COVID-19 patients & 605 \\
\hline NCT04340557 & Recruiting & Interventional & $\begin{array}{l}\text { Investigation of ARBs on progression to acute respiratory distress syndrome with } \\
\text { SARS-CoV-2 infection }\end{array}$ & 100 \\
\hline NCT04337190 & Recruiting & Observational & $\begin{array}{l}\text { Determining ACE2 level and activity in patients with SARS-CoV-2 infection admitted to } \\
\text { ICU }\end{array}$ & 100 \\
\hline NCT04335786 & Recruiting & Interventional & $\begin{array}{l}\text { Investigation of valsartan for prevention of acute respiratory distress syndrome in } \\
\text { hospitalized patients with COVID-19 }\end{array}$ & 651 \\
\hline NCT04337008 & Recruiting & Interventional & Effectiveness of RAS blocker treatments in patients with COVID-19 & 50 \\
\hline NCT04287686 & Withdrawn & Interventional & $\begin{array}{l}\text { Recombinant human angiotensin-converting enzyme } 2 \text { as a treatment for patients with } \\
\text { COVID-19 }\end{array}$ & 0 \\
\hline
\end{tabular}

\section{Conclusions}

The extent of ACE2 expression on the cell surface would seem to play a regulatory role in managing COVID-19 patients with a CVD background or heart failure. As the entry of SARS-CoV-2 into the host cells mainly requires ACE2, the use of inhibitors, which results in the overexpression of ACE2, may increase the susceptibility to a higher virus load. This additional load can then lead to a dose-dependent inflammatory response and possibly viral-induced cardiovascular damage following impairment of cross-talk between resident cardiac cells [92]. 
On the other hand, the discontinuation of RAS system inhibitors strongly promotes cardiovascular dysfunction due to excess Ang II, which in turn has an unfavorable impact on the cardiovascular system especially in critically ill coronavirus patients whose gas exchange between alveolar spaces and capillaries is seriously impaired and who need extra backup from the heart apparatus [93]. Unraveling how to halt viral binding to hot spots without impairing ACE2 activity could provide new avenues for protection against both Ang II and SARS-CoV-2-induced cardiovascular injury.

Code availability Not applicable.

Authors' contributions I.R-J. and V.L. designed and managed the project. The other authors contributed equally. All authors discussed and commented on the manuscript, provided critical feedback, and helped shape the final version of the manuscript.

Funding information Internal funds, Scuola Superiore Sant'Anna, Pisa, Italy (V.L.).

Data availability Not applicable.

\section{Compliance with ethical standards}

Conflict of interest The authors declare that they have no conflict of interest.

Ethics approval Not applicable.

\section{References}

1. Moccia F, Gerbino A, Lionetti V, Miragoli M, Munaron L, Pagliaro $\mathrm{P}$ et al (2020) COVID-19-associated cardiovascular morbidity in older adults: a position paper from the Italian Society of Cardiovascular Researches. GeroScience.:1-29

2. Brojakowska A, Narula J, Shimony R, Bander J (2020) Clinical implications of SARS-Cov2 interaction with renin angiotensin system. J Am Coll Cardiol 75:3085-3095

3. Rahimi F, Abadi ATB (2020) Challenges of managing the asymptomatic carriers of SARS-CoV-2. Travel Med Infect Dis 101677. https://doi.org/10.1016/j.tmaid.2020.101677

4. Wrapp D, Wang N, Corbett KS, Goldsmith JA, Hsieh C-L, Abiona O, Graham BS, McLellan JS (2020) Cryo-EM structure of the 2019-nCoV spike in the prefusion conformation. Science. 367(6483):1260-1263

5. Lamers MM, Beumer J, van der Vaart J, Knoops K, Puschhof J, Breugem TI, Ravelli RBG, Paul van Schayck J, Mykytyn AZ, Duimel HQ, van Donselaar E, Riesebosch S, Kuijpers HJH, Schipper D, van de Wetering WJ, de Graaf M, Koopmans M, Cuppen E, Peters PJ, Haagmans BL, Clevers H (2020) SARSCoV-2 productively infects human gut enterocytes. Science. 369: $50-54$

6. Sungnak W, Huang N, Bécavin C, Berg M, Queen R, Litvinukova $M$ et al (2020) SARS-CoV-2 entry factors are highly expressed in nasal epithelial cells together with innate immune genes. Nat Med 26(5):681-687

7. Zhou L, Xu Z, Castiglione GM, Soiberman US, Eberhart CG, Duh EJ (2020) ACE2 and TMPRSS2 are expressed on the human ocular surface, suggesting susceptibility to SARS-CoV-2 infection. Ocular Surf 18:537-544

8. Guo J, Wei X, Li Q, Li L, Yang Z, Shi Y, Qin Y, Zhang X, Wang X, Zhi X, Meng D (2020) Single-cell RNA analysis on ACE2 expression provides insights into SARS-CoV-2 potential entry into the bloodstream and heart injury. J Cell Physiol. https://doi.org/10. 1002/jcp.29802

9. Li YC, Bai WZ, Hashikawa T (2020) The neuroinvasive potential of SARS-CoV2 may play a role in the respiratory failure of COVID-19 patients. J Med Virol 92(6):552-555

10. Gattinoni L, Chiumello D, Rossi S (2020) COVID-19 pneumonia: ARDS or not? Crit Care 24:154. https://doi.org/10.1186/s13054020-02880-Z

11. Chen N, Zhou M, Dong X, Qu J, Gong F, Han Y, Qiu Y, Wang J, Liu Y, Wei Y, Xia J', Yu T, Zhang X, Zhang L (2020) Epidemiological and clinical characteristics of 99 cases of 2019 novel coronavirus pneumonia in Wuhan, China: a descriptive study. Lancet 395(10223):507-513

12. Huang C, Wang Y, Li X, Ren L, Zhao J, Hu Y, Zhang L, Fan G, Xu J, Gu X, Cheng Z, Yu T, Xia J, Wei Y, Wu W, Xie X, Yin W, Li H, Liu M, Xiao Y, Gao H, Guo L, Xie J, Wang G, Jiang R, Gao Z, Jin Q, Wang J, Cao B (2020) Clinical features of patients infected with 2019 novel coronavirus in Wuhan, China. Lancet 395(10223):497506

13. Russo V, Rago A, Carbone A, Bottino R, Ammendola E, Della Cioppa N, Galante D, Golino P, Nigro G (2020) Atrial fibrillation in COVID-19: from epidemiological association to pharmacological implications. J Cardiovasc Pharmacol 76:138-145. https://doi. org/10.1097/FJC.0000000000000854

14. Iba T, Levy JH, Levi M, Connors JM, Thachil J Coagulopathy of coronavirus disease 2019. Crit Care Med:2020

15. Yang C, Jin Z (2020) An acute respiratory infection runs into the most common noncommunicable epidemic - COVID-19 and cardiovascular diseases. JAMA Cardiol 5:743. https://doi.org/10. 1001/jamacardio.2020.0934

16. Alasady M, Abhayaratna WP, Leong DP, Lim HS, Abed HS, Brooks AG, Mattchoss S, Roberts-Thomson KC, Worthley MI, Chew DP, Sanders P (2011) Coronary artery disease affecting the atrial branches is an independent determinant of atrial fibrillation after myocardial infarction. Heart Rhythm 8(7):955-960

17. Chandran S, Watkins J, Abdul-Aziz A, Shafat M, Calvert PA, Bowles KM et al (2017) Inflammatory differences in plaque erosion and rupture in patients with ST-segment elevation myocardial infarction. J Am Heart Assoc 6(5):e005868

18. Markousis-Mavrogenis G, Tromp J, Ouwerkerk W, Devalaraja M, Anker SD, Cleland JG, Dickstein K, Filippatos GS, Harst P, Lang CC, Metra M, Ng LL, Ponikowski P, Samani NJ, Zannad F, Zwinderman AH, Hillege HL, Veldhuisen DJ, Kakkar R, Voors AA, Meer P (2019) The clinical significance of interleukin-6 in heart failure: results from the BIOSTAT-CHF study. Eur J Heart Fail 21(8):965-973

19. Wang D, Hu B, Hu C, Zhu F, Liu X, Zhang J, Wang B, Xiang H, Cheng Z, Xiong Y, Zhao Y, Li Y, Wang X, Peng Z (2020) Clinical characteristics of 138 hospitalized patients with 2019 novel coronavirus-infected pneumonia in Wuhan, China. Jama 323(11): 1061-1069

20. Zhou P, Yang X-L, Wang X-G, Hu B, Zhang L, Zhang W et al (2020) A pneumonia outbreak associated with a new coronavirus of probable bat origin. Nature 579(7798):270-273

21. Li X, Guan B, Su T, Liu W, Chen M, Waleed KB et al (2020) Impact of cardiovascular disease and cardiac injury on in-hospital mortality in patients with COVID-19: a systematic review and meta-analysis. Heart. 106:1142-1147

22. Inciardi RM, Adamo M, Lupi L, Cani DS, Di Pasquale M, Tomasoni D et al (2020) Characteristics and outcomes of patients 
hospitalized for COVID-19 and cardiac disease in Northern Italy. Eur Heart J 41(19):1821-1829

23. Shi S, Qin M, Shen B, Cai Y, Liu T, Yang F, Gong W, Liu X, Liang J, Zhao Q, Huang H, Yang B, Huang C (2020) Association of cardiac injury with mortality in hospitalized patients with COVID-19 in Wuhan, China. JAMA Cardiol 5:802

24. Escobales N, Nuñez RE, Javadov S (2019) Mitochondrial angiotensin receptors and cardioprotective pathways. Am J Phys Heart Circ Phys 316(6):H1426-H1H38

25. Crowley SD, Gurley SB, Oliverio MI, Pazmino AK, Griffiths R, Flannery PJ, Spurney RF, Kim HS, Smithies O, le TH, Coffman TM (2005) Distinct roles for the kidney and systemic tissues in blood pressure regulation by the renin-angiotensin system. J Clin Invest 115(4):1092-1099

26. Pagliaro P, Penna C (2005) Rethinking the renin-angiotensin system and its role in cardiovascular regulation. Cardiovasc Drugs Ther 19(1):77-87

27. Oudit GY, Zhong J, Basu R, Guo D, Penninger JM, Kassiri Z (2010) Angiotensin converting enzyme 2 suppresses pathological hypertrophy, myocardial fibrosis and diastolic dysfunction. J Card Fail 16(8):S16

28. Lionetti V (2016) Simultaneous exposure to nitric oxide inhibition and angiotensin II overload: is it a murine model of mitochondrial dysfunction in nonischemic heart failure? American Physiological Society Bethesda, MD

29. Pugliese NR, Masi S, Taddei S (2020) The renin-angiotensinaldosterone system: a crossroad from arterial hypertension to heart failure. Heart Fail Rev 25(1):31-42

30. de Gasparo M (2002) Angiotensin II and nitric oxide interaction. Heart Fail Rev 7(4):347-358

31. Landmesser U, Spiekermann S, Preuss C, Sorrentino S, Fischer D, Manes C, Mueller M, Drexler H (2007) Angiotensin II induces endothelial xanthine oxidase activation: role for endothelial dysfunction in patients with coronary disease. Arterioscler Thromb Vasc Biol 27(4):943-948

32. Clancy P, Koblar SA, Golledge J (2014) Angiotensin receptor 1 blockade reduces secretion of inflammation associated cytokines from cultured human carotid atheroma and vascular cells in association with reduced extracellular signal regulated kinase expression and activation. Atherosclerosis. 236(1):108-115

33. Dushpanova A, Agostini S, Ciofini E, Cabiati M, Casieri V, Matteucci M, del Ry S, Clerico A, Berti S, Lionetti V (2016) Gene silencing of endothelial von Willebrand factor attenuates angiotensin II-induced endothelin-1 expression in porcine aortic endothelial cells. Sci Rep 6:30048

34. Hedner T, Samuelsson O, Lunde H, Lindholm L, Andren L, Wiholm B-E (1992) Angio-oedema in relation to treatment with angiotensin converting enzyme inhibitors. Br Med J 304(6832): 941-946

35. Nussberger J, Cugno M, Cicardi M (2002) Bradykinin-mediated angioedema. N Engl J Med 347(8):621-622

36. Lin RY, Cannon AG, Teitel AD (2005) Pattern of hospitalizations for angioedema in New York between 1990 and 2003. Ann Allergy Asthma Immunol 95(2):159-166

37. Fukuta H, Goto T, Wakami K, Kamiya T, Ohte N (2020) Effect of renin-angiotensin system inhibition on cardiac structure and function and exercise capacity in heart failure with preserved ejection fraction: a meta-analysis of randomized controlled trials. Heart Fail Rev:1-8

38. Fattah C, Nather K, McCarroll CS, Hortigon-Vinagre MP, Zamora $\mathrm{V}$, Flores-Munoz M et al (2016) Gene therapy with angiotensin-(19) preserves left ventricular systolic function after myocardial infarction. J Am Coll Cardiol 68(24):2652-2666

39. Wang W, Bodiga S, Das SK, Lo J, Patel V, Oudit GY (2012) Role of ACE2 in diastolic and systolic heart failure. Heart Fail Rev 17(4 5):683-691
40. Ferrario CM, Trask AJ, Jessup JA (2005) Advances in biochemical and functional roles of angiotensin-converting enzyme 2 and angiotensin-(1-7) in regulation of cardiovascular function. Am J Phys Heart Circ Phys 289(6):H2281-H2H90. https://doi.org/10.1152/ ajpheart.00618.2005

41. Simoes e Silva A, Silveira K, Ferreira A, Teixeira M (2013) ACE2, angiotensin-(1-7) and $\mathrm{M}$ as receptor axis in inflammation and fibrosis. Br J Pharmacol 169(3):477-492

42. Khan A, Benthin C, Zeno B, Albertson TE, Boyd J, Christie JD, Hall R, Poirier G, Ronco JJ, Tidswell M, Hardes K, Powley WM, Wright TJ, Siederer SK, Fairman DA, Lipson DA, Bayliffe AI, Lazaar AL (2017) A pilot clinical trial of recombinant human angiotensin-converting enzyme 2 in acute respiratory distress syndrome. Crit Care 21(1):234

43. Pang XF, Liu RM, Xia YF (2019) Effects of inhibitors of the reninangiotensin system on reducing blood pressure and expression of inflammatory factors in CHD patients: a network meta-analysis. J Cell Physiol 234(5):5988-5997

44. Nussberger J, Cugno M, Amstutz C, Cicardi M, Pellacani A, Agostoni A (1998) Plasma bradykinin in angio-oedema. Lancet 351(9117):1693-1697

45. Byrd JB, Touzin K, Sile S, Gainer JV, Yu C, Nadeau J, Adam A, Brown NJ (2008) Dipeptidyl peptidase IV in angiotensinconverting enzyme inhibitor-associated angioedema. Hypertension. 51(1):141-147

46. Taddei S, Bortolotto L (2016) Unraveling the pivotal role of bradykinin in ACE inhibitor activity. Am J Cardiovasc Drugs 16(5):309321

47. Ceconi C, Francolini G, Olivares A, Comini L, Bachetti T, Ferrari R (2007) Angiotensin-converting enzyme (ACE) inhibitors have different selectivity for bradykinin binding sites of human somatic ACE. Eur J Pharmacol 577(1-3):1-6

48. Taddei S, Virdis A, Ghiadoni L, Sudano I, Salvetti A (2002) Effects of antihypertensive drugs on endothelial dysfunction. Drugs. 62(2): 265-284

49. Suwaidi JA, Hamasaki S, Higano ST, Nishimura RA, Holmes DR Jr, Lerman A (2000) Long-term follow-up of patients with mild coronary artery disease and endothelial dysfunction. Circulation. 101(9):948-954

50. Schächinger V, Britten MB, Zeiher AM (2000) Prognostic impact of coronary vasodilator dysfunction on adverse long-term outcome of coronary heart disease. Circulation. 101(16):1899-1906

51. Wang D-z, Chao L, Chao J (1997) Hypotension in transgenic mice overexpressing human bradykinin B2 receptor. Hypertension. 29(1):488-493

52. Agata J, Ura N, Yoshida H, Shinshi Y, Sasaki H, Hyakkoku M et al (2006) Olmesartan is an angiotensin II receptor blocker with an inhibitory effect on angiotensin-converting enzyme. Hypertens Res 29(11):865-874

53. Igase M, Strawn WB, Gallagher PE, Geary RL, Ferrario CM (2005) Angiotensin II AT1 receptors regulate ACE2 and angiotensin-(1-7) expression in the aorta of spontaneously hypertensive rats. Am J Phys Heart Circ Phys 289(3):H1013-H10H9

54. Kiya Y, Miura S-I, Fujino M, Imaizumi S, Karnik SS, Saku K (2010) Clinical and pharmacotherapeutic relevance of the doublechain domain of the angiotensin II type 1 receptor blocker olmesartan. Clin Exp Hypertens 32(2):129-136

55. Kostis WJ, Shetty M, Chowdhury YS, Kostis JB (2018) ACE inhibitor-induced angioedema: a review. Curr Hypertens Rep 20(7):55

56. Keidar S, Gamliel-Lazarovich A, Kaplan M, Pavlotzky E, Hamoud S, Hayek T, Karry R, Abassi Z (2005) Mineralocorticoid receptor blocker increases angiotensin-converting enzyme 2 activity in congestive heart failure patients. Circ Res 97(9):946-953

57. Sama IE, Ravera A, Santema BT, van Goor H, ter Maaten JM, Cleland JG et al (2020) Circulating plasma concentrations of 
ACE2 in men and women with heart failure and effects of reninangiotensin-aldosterone-inhibitors. Eur Heart J 41:1810-1817

58. Wang J, He W, Guo L, Zhang Y, Li H, Han S, Shen D (2017) The ACE2-Ang (1-7)-Mas receptor axis attenuates cardiac remodeling and fibrosis in post-myocardial infarction. Mol Med Rep 16(2): 1973-1981

59. Iyer SN, Chappell MC, Averill DB, Diz DI, Ferrario CM (1998) Vasodepressor actions of angiotensin-(1-7) unmasked during combined treatment with lisinopril and losartan. Hypertension. 31(2): 699-705

60. Gallagher PE, Ferrario CM, Tallant EA (2008) Regulation of ACE2 in cardiac myocytes and fibroblasts. Am J Phys Heart Circ Phys 295(6):H2373-H23H9

61. Kuba K, Imai Y, Rao S, Gao H, Guo F, Guan B, Huan Y, Yang P, Zhang Y, Deng W, Bao L, Zhang B, Liu G, Wang Z, Chappell M, Liu Y, Zheng D, Leibbrandt A, Wada T, Slutsky AS, Liu D, Qin C, Jiang C, Penninger JM (2005) A crucial role of angiotensin converting enzyme 2 (ACE2) in SARS coronavirus-induced lung injury. Nat Med 11(8):875-879

62. Verdecchia P, Cavallini C, Spanevello A, Angeli F (2020) The pivotal link between ACE2 deficiency and SARS-CoV-2 infection. Eur J Intern Med 76:14-20

63. Ye R, Liu Z (2020) ACE2 exhibits protective effects against LPSinduced acute lung injury in mice by inhibiting the LPS-TLR4 pathway. Exp Mol Pathol 113:104350

64. Doerschug KC, Delsing AS, Schmidt GA, Ashare A (2010) Reninangiotensin system activation correlates with microvascular dysfunction in a prospective cohort study of clinical sepsis. Crit Care 14(1):R24

65. Wenz M, Hoffmann B, Bohlender J, Kaczmarczyk G (2000) Angiotensin II formation and endothelin clearance in ARDS patients in supine and prone positions. Intensive Care Med 26(3): 292-298

66. Hemnes AR, Rathinasabapathy A, Austin EA, Brittain EL, Carrier EJ, Chen X et al (2018) A potential therapeutic role for angiotensinconverting enzyme 2 in human pulmonary arterial hypertension. Eur Respir J 51(6)

67. Fagerberg L, Hallström BM, Oksvold P, Kampf C, Djureinovic D, Odeberg J, Habuka M, Tahmasebpoor S, Danielsson A, Edlund K, Asplund A, Sjöstedt E, Lundberg E, Szigyarto CAK, Skogs M, Takanen JO, Berling H, Tegel H, Mulder J, Nilsson P, Schwenk JM, Lindskog C, Danielsson F, Mardinoglu A, Sivertsson Å, von Feilitzen K, Forsberg M, Zwahlen M, Olsson IM, Navani S, Huss M, Nielsen J, Ponten F, Uhlén M (2014) Analysis of the human tissue-specific expression by genome-wide integration of transcriptomics and antibody-based proteomics. Mol Cell Proteomics 13(2):397-406

68. Tipnis SR, Hooper NM, Hyde R, Karran E, Christie G, Turner AJ (2000) A human homolog of angiotensin-converting enzyme cloning and functional expression as a captopril-insensitive carboxypeptidase. J Biol Chem 275(43):33238-33243

69. Hoffmann M, Kleine-Weber H, Schroeder S, Krüger N, Herrler T, Erichsen S, Schiergens TS, Herrler G, Wu NH, Nitsche A, Müller MA, Drosten C, Pöhlmann S (2020) SARS-CoV-2 cell entry depends on ACE2 and TMPRSS2 and is blocked by a clinically proven protease inhibitor. Cell. 181:271-280.e8

70. Ehlers MR, Riordan JF (1991) Angiotensin-converting enzyme: zinc-and inhibitor-binding stoichiometries of the somatic and testis isozymes. Biochemistry. 30(29):7118-7126

71. Soubrier F, Alhenc-Gelas F, Hubert C, Allegrini J, John M, Tregear G, Corvol P (1988) Two putative active centers in human angiotensin I-converting enzyme revealed by molecular cloning. Proc Natl Acad Sci 85(24):9386-9390

72. Crackower MA, Sarao R, Oudit GY, Yagil C, Kozieradzki I, Scanga SE, Oliveira-dos-Santos AJ, da Costa J, Zhang L, Pei Y, Scholey J, Ferrario CM, Manoukian AS, Chappell MC, Backx PH,
Yagil Y, Penninger JM (2002) Angiotensin-converting enzyme 2 is an essential regulator of heart function. Nature. 417(6891):822-828

73. Iwata M, Cowling RT, Gurantz D, Moore C, Zhang S, Yuan JX-J, Greenberg BH (2005) Angiotensin-(1-7) binds to specific receptors on cardiac fibroblasts to initiate antifibrotic and antitrophic effects. Am J Phys Heart Circ Phys 289(6):H2356-H2H63

74. Haga S, Yamamoto N, Nakai-Murakami C, Osawa Y, Tokunaga K, Sata T, Yamamoto N, Sasazuki T, Ishizaka Y (2008) Modulation of TNF- $\alpha$-converting enzyme by the spike protein of SARS-CoV and ACE2 induces TNF- $\alpha$ production and facilitates viral entry. Proc Natl Acad Sci 105(22):7809-7814

75. Perlman S, Netland J (2009) Coronaviruses post-SARS: update on replication and pathogenesis. Nat Rev Microbiol 7(6):439-450

76. Li F (2016) Structure, function, and evolution of coronavirus spike proteins. Ann Rev Virol 3:237-261

77. Shang J, Ye G, Shi K, Wan Y, Luo C, Aihara H, Geng Q, Auerbach A, Li F (2020) Structural basis of receptor recognition by SARSCoV-2. Nature. 581(7807):221-224

78. Li F, Li W, Farzan M, Harrison SC (2005) Structure of SARS coronavirus spike receptor-binding domain complexed with receptor. Science. 309(5742): 1864-1868

79. Li W, Moore MJ, Vasilieva N, Sui J, Wong SK, Berne MA, Somasundaran M, Sullivan JL, Luzuriaga K, Greenough TC, Choe H, Farzan M (2003) Angiotensin-converting enzyme 2 is a functional receptor for the SARS coronavirus. Nature. 426(6965): $450-454$

80. Imai Y, Kuba K, Rao S, Huan Y, Guo F, Guan B, Yang P, Sarao R, Wada T, Leong-Poi H, Crackower MA, Fukamizu A, Hui CC, Hein L, Uhlig S, Slutsky AS, Jiang C, Penninger JM (2005) Angiotensinconverting enzyme 2 protects from severe acute lung failure. Nature. 436(7047):112-116. https://doi.org/10.1038/nature03712

81. Ishiyama Y, Gallagher PE, Averill DB, Tallant EA, Brosnihan KB, Ferrario CM (2004) Upregulation of angiotensin-converting enzyme 2 after myocardial infarction by blockade of angiotensin II receptors. Hypertension. 43(5):970-976

82. Epelman S, Tang WW, Chen SY, Van Lente F, Francis GS, Sen S (2008) Detection of soluble angiotensin-converting enzyme 2 in heart failure: insights into the endogenous counter-regulatory pathway of the renin-angiotensin-aldosterone system. J Am Coll Cardiol 52(9):750-754

83. Kreutz R, Algharably EAE-H, Azizi M, Dobrowolski P, Guzik T, Januszewicz A, Persu A, Prejbisz A, Riemer TG, Wang JG, Burnier $M(2020)$ Hypertension, the renin-angiotensin system, and the risk of lower respiratory tract infections and lung injury: implications for COVID-19 European Society of Hypertension COVID-19 Task Force Review of Evidence. Cardiovasc Res 116:1688-1699

84. Fehr AR, Perlman S (2015) Coronaviruses: an overview of their replication and pathogenesis. In: Maier H., Bickerton E., Britton P. (eds) Coronaviruses. Methods in Molecular Biology, vol 1282. Humana Press, New York, NY. https://doi.org/10.1007/978-14939-2438-7 1

85. Patel VB, Zhong J-C, Grant MB, Oudit GY (2016) Role of the ACE2/angiotensin 1-7 axis of the renin-angiotensin system in heart failure. Circ Res 118(8):1313-1326

86. Meng J, Xiao G, Zhang J, He X, Ou M, Bi J, Yang R, di W, Wang Z, Li Z, Gao H, Liu L, Zhang G (2020) Renin-angiotensin system inhibitors improve the clinical outcomes of COVID-19 patients with hypertension. Emerg Microbes Infect 9(1):757-760

87. Danser AJ, Epstein M, Batlle D (2020) Renin-angiotensin system blockers and the COVID-19 pandemic: at present there is no evidence to abandon renin-angiotensin system blockers. Hypertension. 75(6):1382-1385

88. Bai F, Pang X-F, Zhang L-H, Wang N-P, McKallip RJ, Garner RE et al (2016) Angiotensin II AT1 receptor alters ACE2 activity, eNOS expression and CD44-hyaluronan interaction in rats with hypertension and myocardial fibrosis. Life Sci 153:141-152 
89. Mazak I, Fiebeler A, Muller DN, Park J-K, Shagdarsuren E, Lindschau C, Dechend R, Viedt C, Pilz B, Haller H, Luft FC (2004) Aldosterone potentiates angiotensin II-induced signaling in vascular smooth muscle cells. Circulation. 109(22):2792-2800

90. Bozkurt B, Kovacs R, Harrington B (2020) Joint HFSA/ACC/AHA statement addresses concerns re: using RAAS antagonists in COVID-19. J Card Fail 26(5):370

91. Kuster GM, Pfister O, Burkard T, Zhou Q, Twerenbold R, Haaf P et al (2020) SARS-CoV2: should inhibitors of the reninangiotensin system be withdrawn in patients with COVID-19? Eur Heart J 41:1801-3. https://doi.org/10.1093/eurheartj/ehaa235.
92. Lionetti V, Bianchi G, Recchia FA, Ventura C (2010) Control of autocrine and paracrine myocardial signals: an emerging therapeutic strategy in heart failure. Heart Fail Rev 15(6):531-542

93. Lionetti V, Barile L (2019) Perioperative cardioprotection: back to bedside. Minerva Anestesiol 86:445-54. https://doi.org/10.23736/ S0375-9393.19.13848-5

Publisher's note Springer Nature remains neutral with regard to jurisdictional claims in published maps and institutional affiliations. 